\title{
The role of the nurse in caring for the child with cancer: integration review
}

\begin{abstract}
Objective: To know the role of nurses in the care of children with cancer.

Method: This is an integrative review, with a survey of articles in the LILACS, SCIELO, BDENF and PubMed databases, published between 2005 and 2015, with 26 articles being selected for analysis and discussion.

Analysis and discussion: As for the year of publication, it was verified that the years with the most publications on the subject were - 2008, 2010, 2012 to 2015, concentrating 24(91.97\%) publications. The nursing team should monitor the evolution of the disease by supporting the child and their families, thus facilitating the development of the treatment, thus easing the stress of the child and family.
\end{abstract}

Final considerations: It is up to the professional nurse to develop a relationship of trust with the child with cancer and its relatives, in order to facilitate care and treatment.

Keywords: pediatrics, pediatric nursing, childhood cancer, family, recreational, therapeutic
Volume 2 Issue 4 - 2018

\begin{abstract}
Maurício de Oliveira Chaves, Gabriela Pereira Ribeiro, Karine Aguiar Amorim Departamento de Enfermagem, Universidade Catelica de Brasilia, Brazil
\end{abstract}

Correspondence: Maurício de Oliveira Chaves, Departamento de Enfermagem, Universidade Catelica de Brasilia, Qs 7 lote OI - Aguas Clara, Brasilia, DF, CEP:7I 966-700, Brazil, Tel 556 I 996512156, email chamorsemfim@gmail.com

Received: May 10,2018 | Published: July 31, 2018

\section{Introduction}

Despite the advances of science, childhood cancer and its confrontation still constitutes a great challenge for the whole society. Although considered rare in Brazil, pediatric malignancies in children and adolescents from 0 to 19 years of age were the second cause of death in 2014, representing $7 \%$ of the deaths, being surpassed only by deaths due to external causes. In this age group cancer is the pathology that kills the most. In 2014, the median percentage of neoplasias was $2 \%$ in the infant population ( 0 to 14 years old), with a higher frequency of leukemias $(33.2 \%)$, followed by central nervous system tumors $(16.0 \%)$ and of lymphomas (13.7\%). ${ }^{1}$ Currently, childhood cancers, that is, cancers occurring before 15 years of age, represent between $0.5 \%$ and $4.6 \%$ of the total number of cancer cases in a population, with a global incidence rate ranging from 50 to 200 per million children per year, ${ }^{2}$ so it is necessary to seek improvements in the services provided to treat them properly. ${ }^{3}$ This is a disease that affects not only the child, but the entire family, since it is the family that is primarily responsible for the care of the child. ${ }^{4}$

In this context, the pediatric oncology professional must go beyond the application of technical and scientific knowledge, offering the child and his family a humanized care ${ }^{5-8}$ aiming at the promotion of health, quality of life, comfort and well-being of them. ${ }^{7,8}$ It is necessary that all those involved in care are more sensitive and responsible, open to forming partnerships with families and mobilizing possible social support networks, in order to create links. ${ }^{3}$ Among the professionals who deal with the oncological child, the Nurses stand out, once they assume a position of support, dealing daily and directly with the child. It has an important role in guiding the patient and his family in the experience of the disease process, treatment and rehabilitation, definitively affecting future quality of life. It acts to alleviate the suffering caused by hospitalization, through the humanization of the care and development of the ludic. ${ }^{8,9}$ The nurse has an indispensable role in the care of the oncological child, and must act consciously, reflexively and critically in the care of the child and the family that is under his care, ${ }^{8}$ carefully considering the particularities and singularities of each, ${ }^{5,8}$ they are sensitized by the whole situation that cancer imposes. It is necessary that the nurse professional understands the pain of the other, in order to relieve it, seeking recovery and a good standard of quality of life of the pediatric patient. ${ }^{10}$ Therefore, the present study aims to know the role of nurses in the care of children with cancer.

\section{Methods}

The present research is an integrative review of the literature, being a research method that allows the search, critical evaluation and synthesis of the available evidence of the investigated subject, its final product being the current state of knowledge of the subject investigated, the implementation of effective interventions in health care and the identification of gaps that lead to the development of future research. ${ }^{11}$ This research method provides health professionals with knowledge about a particular theme at different times and places, keeping them up to date and facilitating evidence-based practice based on scientific reasoning, making it an important tool. ${ }^{11,12}$ To carry out the study, the following problem was considered as a guiding question: "What is the role of the nurse in the care of the child with cancer?". In order to carry out the study, the scientific literature was searched through databases: Scientific Electronic Library Online (SCIELO), US National Library of Medicine, National Institutes of Health (PubMed), Latin American and Caribbean Literature in Sciences and Health (LILACS) and Nursing Database (BDENF), referring to the last five years.

For the data collection, controlled descriptors were used to meet the research objectives. Considering the descriptors in Sciences and Health (Decs): "pediatrics", "pediatric nursing", "childhood cancer", "family", "playful" and "therapeutic". The descriptors were combined with the Boolean connective "AND". Remaining in the following order: "pediatrics and pediatric nursing", "childhood cancer and nursing", "childhood cancer and family" and "childhood and playful 
cancer". In addition, materials available from the Ministry of Health (MS) and the World Health Organization (WHO) were used for nursing actions in relation to the pediatric cancer patient.

After the combination of the descriptors, the data sources were submitted to inclusion criteria, being: year of publication from 2005 to 2016, studies in Portuguese and English, whose theme met the research objectives and full text available in indexed databases. Regarding the exclusion criteria, the articles were repeated in a database, which did not meet the objectives of the study, articles available only in summary, and those published without scientific evidence such as editorial, letter to reader, opinion article. The descriptors "pediatrics and pediatric nursing" found 189 articles in the LILACS database, 38 articles in the SciELO database, 7 articles in the PubMed database and 98 articles in the BDENF database. The descriptors "childhood cancer and nursing" found 83 articles in the LILACS database, 15 articles in the SciELO database 8 articles in the PubMed database and 45 articles in the BDENF database. The descriptors "childhood cancer and family" found 109 articles in the LILACS database, 24 articles in the SciELO database, 48 articles in the PubMed database and 30 articles in the BDENF database. The descriptors "childhood and playful cancer" found 2 articles in the LILACS database and 2

Table I List of articles in the title of the article, database, language, type of study and year

\begin{tabular}{|c|c|c|c|c|}
\hline Production title & $\begin{array}{l}\text { Data } \\
\text { base }\end{array}$ & Language & Kind of study & Year \\
\hline $\begin{array}{l}\text { Incidence, mortality and hospital morbidity due to cancer in children, adolescents and } \\
\text { young adults in Brazill }\end{array}$ & PubMed & Portuguese & Cohort study & 2016 \\
\hline World cancer report 20142 & PubMed & English & Cohort study & 2014 \\
\hline Daily life of the family in facing the chronic condition in childhood3 & SciELO & Portuguese & Qualitative study & 2010 \\
\hline Care-Related Stress:The Impact of Childhood Cancer on Parents' Lives4 & SciELO & Portuguese & Exploratory study & 2013 \\
\hline From the diagnosis to the survival of childhood cancer: perspective of children 5 & SciELO & Portuguese & Exploratory study & 2013 \\
\hline $\begin{array}{l}\text { Palliative care in pediatric oncology: perceptions, knowledge and practices of } \\
\text { perspectives in the multiprofessional team } 6\end{array}$ & BDENF & Portuguese & Qualitative study & 2015 \\
\hline The ludic as a strategy in the care of children with cancer7 & LILACS & Portuguese & Exploratory study & 2015 \\
\hline Nursing care for children with cancer: an integrative review of the literature 8 & BDENF & Portuguese & Review study & 2013 \\
\hline The daily lives of parents of children with cancer and hospitalized9 & SciELO & Portuguese & Qualitative study & 2012 \\
\hline Nurses' performance in the care of children with cancer: a literature review 10 & LILACS & Portuguese & Review study & 2014 \\
\hline Children with cancer and their families I 3 & SciELO & Portuguese & Review study & 2005 \\
\hline Caring in nursing: family and child with cancer pain 14 & LILACS & Portuguese & Exploratory study & 2012 \\
\hline Health care of children with cancer in Brazilian scientific production I5 & BDENF & Portuguese & Review study & 2010 \\
\hline $\begin{array}{l}\text { The perception of family caregivers about chemotherapeutic treatment in children and } \\
\text { adolescents } 16\end{array}$ & LILACS & Portuguese & Qualitative study & 2014 \\
\hline $\begin{array}{l}\text { Chronic disease in childhood: experience of the family in the hospitalization of the } \\
\text { child } 77\end{array}$ & BDENF & Portuguese & Exploratory study & 2006 \\
\hline $\begin{array}{l}\text { (Con) family experience of schoolchild in control of oncological disease: prospects for } \\
\text { pediatric nursing } 19\end{array}$ & LILACS & Portuguese & Qualitative study & 2012 \\
\hline Family life in the face of childhood cancer 20 & LILACS & Portuguese & Qualitative study & 2011 \\
\hline
\end{tabular}

articles in the BDENF database.

\section{Result and discussion}

We selected 63 articles for discussion, but only 26 of these articles met the inclusion criteria of the present study. As for the year of publication, it was verified that there were eight (30.7\%) publications of articles between the years 2005 to 2010 and between the years 2011 to 2016 there were $18(69.3 \%$ ) publications (Table 1). Childhood cancer has a high incidence of cure, but it is still a difficult diagnosis and has an intense repercussion on the life of the child and his family. ${ }^{13,14}$ This pathology imposes great limitations, interrupts daily activities 10 and requires several moments of hospitalization. ${ }^{7}$ In this context, the presence of the mother and/or family member during the treatment becomes indispensable. ${ }^{15}$ Pediatric neoplasia generates feelings of insecurity in the family, doubts about the diagnosis, uncertainties about the future of the child, ${ }^{3,16}$ fear of losing your loved one, causing a lot of pain and mental suffering., ${ }^{3,14}$ These families often suffer from a stress generated by hospitalization and distancing from the family routine, increasing the sense of impotence in the development of health care, ${ }^{3,13}$ loneliness, neglect, leaving them vulnerable. 
Table continued...

\begin{tabular}{|c|c|c|c|c|}
\hline Production title & $\begin{array}{l}\text { Data } \\
\text { base }\end{array}$ & Language & Kind of study & Year \\
\hline The family of the oncological child in palliative care: the look of the nursing team 2 I & BDENF & Portuguese & Qualitative study & 2011 \\
\hline Unveiling humanized care: perceptions of nurses in pediatric oncology 22 & SciELO & Portuguese & Exploratory study & 2013 \\
\hline $\begin{array}{l}\text { Evaluation of the psychic suffering of the accompanying mother in pediatric joint } \\
\text { housing } 23\end{array}$ & SciELO & Portuguese & Qualitative study & 2009 \\
\hline $\begin{array}{l}\text { Non-pharmacological methods for the control of pediatric oncological pain: a nursing } \\
\text { team's view24 }\end{array}$ & SciELO & Portuguese & Exploratory study & 2015 \\
\hline The role of the nurse in the child with cancer: palliative care 25 & LILACS & Portuguese & Qualitative study & 2014 \\
\hline Strategies for Coping with Parents of Children in Cancer Treatment26 & SciELO & Portuguese & Review study & 2008 \\
\hline Humanization in pediatrics: the toy with nursing assistance in hospitalized children 27 & LILACS & Portuguese & Review study & 2010 \\
\hline $\begin{array}{l}\text { Childhood cancer: feelings manifested by children in chemotherapy during therapeutic } \\
\text { toy sessions } 28\end{array}$ & LILACS & Portuguese & Qualitative study & 2012 \\
\hline
\end{tabular}

Faced with this reality, it is necessary for the health team to identify these demands and to include the family in the perspective of car,e, ${ }^{3}$ being the nurse responsible for facilitating the greater awareness of the companion, thus promoting the strengthening of the family-child bond. ${ }^{7}$ It should be noted that the multiprofessional team must attend the child and his family in an integral and humanized way, ${ }^{15}$ promoting measures that favor their well being and reduce discomforts arising from hospitalization, alleviating physical and emotional symptoms, among others. ${ }^{7,15}$ The support should come from the entire multidisciplinary hospital team, however, what ends up happening is that the nurses end up creating a bigger bond with the patients and their relatives, for spending more time together., ${ }^{9-20}$ Making nursing essential in the care of children with cancer, it sets up a complex action that involves the dialogical relationship life and death, order and disorder ${ }^{8}$. Allowing the professional to understand the need for a humanized and qualified practice in the care of the child and his family. ${ }^{8,21}$

The professional nurse is the first contact of the family in the universe so feared and unknown that is the hospital environment, ${ }^{14}$ therefore, the importance of the relationship between patient, nursing team and family, in the caring process, ${ }^{9}$ includes to know the family structure, its dynamics and existing and established interactions in the contexts in which it transits, to meet its real needs, seeking to create, strengthen and maintain supporting links to reduce the stress load of the primary caregiver of children with cancer. ${ }^{5}$ Caring is intrinsically related to understanding the situation by putting yourself in the other's place $^{14}$, evidencing the need of a management of the dynamic care to the child with cancer and that the same is carried out according to the situations experienced. ${ }^{8}$ The nurse needs to know how to choose the right time and this requires some sensitivity to identify when a moment is not suitable for performing a particular procedure, especially since it is a child. At the same time, he realizes the need to impose limits on the child, with a certain tolerance, so as not to harm his health during treatment. ${ }^{22}$ Some studies affirm that the nurse must know the routine of the child and his/her relatives, in order to establish a bond with them. ${ }^{3,19-23}$

When hospitalized, the child suffers a rupture of his daily life, where the moment of lack of presence occurs, and it is where the nurse plays an important role, where he offers support and special attention to the child. ${ }^{14}$ To the nursing it fits, as it has the capacity to evaluate the pain, to minimize the pain sensation, ${ }^{8,14,24}$ and to share experiences with the child and the family, which should be considered as the first care provider nucleus, in order to meet the needs of the child with cancer pain. ${ }^{14}$ The relationship of trust/empathy between the nurse practitioner, the child and the family goes through the whole process of diagnosis, treatment and control, with periods of greater and lesser approximation. ${ }^{4,5,7,19,23}$ Throughout the treatment process the interaction with the family is fundamental, enabling the exchange of information and knowledge ${ }^{19}$ through sensitive listening, with the queries being solicited, ${ }^{4,25}$ involving the relative in the health care of the pediatric patient. ${ }^{6,26}$ The relationship of trust, respect and support between health professionals and the family allows the necessary conditions for the child and the family to support the feelings experienced in facing the pathology. $4,8,9,23$

Another attribution of the nurse is to provide quality of life to the child, for that, play should be valued in their caregiving, ${ }^{25}$ because play is a valuable resource for children to express their feelings and facilitate communication, conquering cooperation for the necessary procedures. ${ }^{27}$ Some studies have cited playful activities as development to improve anxiety, allow the child to open up and reveal what he thinks about what is happening. ${ }^{10}$ When playing and interacting with the child, the nurse practitioner establishes an affectionate relationship and then becomes the person to whom the child seeks to play again, or when he feels threatened by the innumerable procedures to which he is subjected. ${ }^{22}$ It should be noted that the nurse is responsible for managing the care provided by her nursing team, having the role of planning, organizing, supervising and implementing nursing care. As a leader, the nurse must manage the team and motivate them to competently and effectively perform their duties. Considering that, although nurses are a vital professional in pediatric oncology, their performance should be developed in conjunction with the work of other health professionals. ${ }^{8}$

Care with the oncological child is a challenge for nurses and their staff, as they are faced with situations of extreme suffering of the child and his family, which often generate emotional and physical exhaustion in the health professional. This professional often feels sad and distressed with the situations experienced, also needing psychological support and training to perform in the area of 
pediatric oncology. ${ }^{8}$ Emphasis is given to the need for institutions to provide professionals with adequate training, development of skills and competencies to work in the field of cancer. ${ }^{8,9}$ It is extremely important that nurses and their team know about cancer, the feelings expressed by the children in treatment and their families, in order to guide the conduct of care that meets the biological and psychological needs of this child. ${ }^{28}$

\section{Final considerations}

Because of the above facts, it can be noted that childhood cancer affects a large part of the child population, this is a disease that affects not only the child, but the whole family, as the family is the main responsible for the care of the child. Regarding the role of nurses in the care of children with cancer, it is up to this professional to meet the needs of the child, family members, caregivers and also assume the managerial role of his team in order to meet the needs of both parties, creating a link between the nursing team, the child and their families, through the humanization of the care and development of playfulness, aiming ease the suffering caused by hospitalization. The team should build the child's trust so that they have the place to support them, follow the evolution of the disease by providing care, such as dressings, administering medications, giving words of support to the patient and family members. It is worth noting that it is not only a personal responsibility of the nurse to develop skills to care for children with cancer, but it is also an institutional and educational responsibility to promote it. The review of the presented literature allowed to visualize a wide theoretical and instrumental scenario that surrounds the studied subject. It is noted that despite the extraordinary advances in medicine currently achieved in relation to childhood cancer, there are still many obstacles to be overcome so that the treatment process does not represent a source of stress and high stress for the child and the family.

\section{Acknowledgements}

None.

\section{Conflict of interest}

The author declares no conflict of interest.

\section{References}

1. Instituto Nacional de Câncer. Coordenação de Prevenção e Vigilância. Incidência, mortalidade e morbidade hospitalar por câncer em crianças, adolescentes e adultos jovens no Brasil: informações dos registros de câncer e do sistema de mortalidade. Rio de Janeiro, Brazil: INCA; 2016. p. 414.

2. World Health Organization. World cancer report 2014. Geneva, Switzerland: WHO; 2014.

3. Silva Mônica de Assis Salviano. Daily life of the family in confronting the chronic condition in childhood. Acta Paulista de Enfermagem. 2010;23(3):359-36.

4. Alves Daniela Fernanda dos Santos, Guirardello Edinêis de Brito, Kurashima Andréa Yamaguchi. Estresse relacionado ao cuidado: o impacto do câncer infantil na vida dos pais. Rev Latino Am Enfermagem. 2013;21(1):356-362.

5. Gomes Isabelle Pimentel, Lima Karinna de Abreu, Rodrigues Larycia Vicente, et al. Do diagnóstico à sobrevivência do câncer infantil: perspectiva de crianças. Texto contexto - enferm. 2013;22(3):671-679.

6. Silva Adriana Ferreira da, Issi Helena Becker, Motta Maria da Graça
Corso da, et al. Cuidados paliativos em oncologia pediátrica: percepcções, saberes e práticas na perspectiva da equipe multiprofissional. Rev Gaúcha Enferm. 2015;36(2):56-62.

7. Lima Kálya Yasmine Nunes de, Santos Viviane Euzébia Pereira. O lúdico como estratégia no cuidado à criança com câncer. Rev Gaúcha Enferm. 2015;36(2):76-81.

8. Silva Thiago Privado da, Joséte Luzia Leite, Nereida Lucia Palko dos Santos, et al. Cuidados de enfermagem à criança com câncer: uma revisão integrativa da literatura. Rev Enferm UFSM. 2013;3(1):68-78.

9. Duarte Maria de Lourdes Custódio, Zanini Lisiane Nunes, Nedel Maria Noemia Birck. O cotidiano dos pais de crianças com câncer e hospitalizadas. Rev Gaúcha Enferm. 2012;33(3):111-118.

10. Souza Luís Paulo Souza e et al. Atuação do enfermeiro na assistência a crianças com câncer: uma revisão de literatura. J Health Sci Inst. 2014;32(2):203-210.

11. Souza Marcela Tavares de, Silva Michelly Dias da, Carvalho Rachel de. Revisão integrativa: o que é e como fazer. Einstein. 2010;8(1):102-106.

12. Mendes Karina Dal Sasso, Silveira Renata Cristina Pereira, Galvão Cristina Maria. Revisão integrativa: método de pesquisa para a incorporação de evidências na saúde e na enfermagem. Texto contexto enferm. 2008;17(4):758-764.

13. Nascimento Lucila Castanheira. Crianças com câncer e suas famílias. Rev Esc Enferm USP. 2005 V.39, no.4, p:469-74.

14. Diefenbach Grassele Denardini Facin, Motta Maria da Graça Corso da. O cuidar em enfermagem: família e criança com dor oncológica. Cogitare Enferm. 2012;17(3):458-463.

15. Mutti Cintia Flores, Paula Cristiane Cardoso de, Souto Marise Dutra. Assistência à saude da criança com cancer na produção cientifica Brasileira. Revista Brasileira de Cancerologia. 2010;56(1):71-83.

16. Kanda Márcia Helena, Divanice Contim, Jurema Ribeiro Luiz Gonçalves, et al. A percepção dos familiares cuidadores sobre o tratamento quimioterápico em crianças e adolescentes. Cogitare Enferm. 2014;19(1):84-88.

17. Silva Fernanda Machado da, Correa Ione. Doença crônica na infância: vivência do familiar na hospitalização da criança. Rev Min Enf. 2006;10(1):18-23.

18. Instituto Nacional De Câncer. Ações de enfermagem para o controle do câncer: uma proposta de integração ensino-serviço. 3. ed. Rio de Janeiro, Brazil: INCA, 2008.

19. Couto Leila Leontina, Oliveira Isabel Cristina dos Santos. (Con)vivência familiar do escolar em controle da doença oncologica: perspectivas para a enfermagem pediatrica. Rev Brasileira de Cancerologia. 2012;58(1):5766.

20. Quirino Daniela Dias. Cotidiano da família no enfrentamento do câncer infantil. João Pessoa: Universidade Federal da Paraíba. 2011.

21. Silva Adriana Ferreira da, Issi Helena Becker, Motta, Maria da Garça Corso da. A família da criança oncológica em cuidados paliativos: o olhar da equipe de enfermagem. Cienc Cuid Saude. 2011;10(4):820-827.

22. Santos Maiara Rodrigues dos et al. Desvelando o cuidado humanizado: percepções de enfermeiros em oncologia pediátrica. Enferm. 2013;22(3).

23. Costa Jaquilene Barreto da, Mombelli Mônica Augusta, Marcon Sonia Silva. Avaliação do sofrimento psíquico da mãe acompanhante em alojamento conjunto pediátrico. Estudos de Psicologia. 2009;26(3):317325 .

24. Chotolli Mayara Ruiz, Luize Paula Batista. Métodos não farmacológicos no controle da dor oncológica pediátrica: visão da equipe de enfermagem. Rev Dor São Paulo. 2015;16(2):109-113. 
25. Monteiro Ana Claúdia Moreira, Benedita Maria Rêgo Deusdará Rodrigues, Sandra Teixeira de Araújo Pacheco, et al. A atuação do enfermeiro junto à criança com câncer: cuidados paliativos. Rev Enferm UERJ. 2014;22(6):778-783.

26. Kohlsdorf Marina, Costa Junior, Áderson Luiz da. Estratégias de enfrentamento de pais de crianças em tratamento de câncer. Estud psicol (Campinas). 2008;25(3):417-429.
27. Silva Sílvia Helena da, Jesus Izabel Cristina de, Santos Rosângela Marques dos. Humanização em pediatria: o brinquedo como recurso na assistência de enfermagem à criança hospitalizada. Pediatria Moderna. 2010;46(3):101-104.

28. Souza Luís Paulo Souza, Raiane Katielle Pereira Silva, Renata Guimarães Amaral, et al. Câncer infantil: sentimentos manifestados por crianças em quimioterapia durante sessões de brinquedo terapêutico. Rev Rene 2012;13(3):686-692. 